\title{
The assessment of the habitat and water quality requirements of the stone crayfish (Austropotamobius torrentium) and noble crayfish (Astacus astacus) species in the rivers from the Anina Mountains (SW Romania)
}

\author{
L. Pârvulescu(1), O. Pacioglu(2), C. Hamchevici(3) \\ Received September 22, 2010 / Reçu le 22 septembre 2010 \\ Revised November 28, 2010 / Révisé le 28 novembre 2010 \\ Accepted December 6, 2010 / Accepté le 6 décembre 2010
}

\section{ABSTRACT}

Key-words: $\quad$ The species Austropotamobius torrentium and Astacus astacus are two Astacus astacus, species known in the EU directives to require deeper understanding of their autecologic requirements before any sustainable conservation efAustropotamobius fort could be successfully applied. Therefore, the paper aims to analyze torrentium, crayfish, the occurrence of these two species of crayfish in the Anina Mountains distribution (Romania) in relation to several physical-chemical indicators measured on site. The results suggest that the anthropogenic impacts registered in some of the sampling sites (e.g. organic pollution and river bed modification) might have triggered the disappearance of both species from the areas of the water sheds situated downstream villages and towns, deforestation sites and sewage treatment plants. The analysis suggest that both species might have similar ecologic requirements, with a BMWP score of 8 (out of a possible 10), therefore good indicators of pristine aquatic environments and with a possible toleration to pollution but only up to a moderate level. Nevertheless, the lack of cohabitation of the populations of both species at a local scale was discussed along with two possible explaining hypotheses: behavioral exclusion or different times and/or modalities of dispersal history.

\section{RÉSUMÉ}

L'évaluation de l'habitat et des exigences de qualité de l'eau de l'écrevisse des torrents (Austropotamobius torrentium) et de l'écrevisse à pieds rouges (Astacus astacus) dans les rivières des montagnes d'Anina (sud-ouest de la Roumanie)

Mots-clés : Astacus astacus,
Austropotamobius torrentium et Astacus astacus sont deux espèces de I'UE reconnues comme nécessitant une meilleure compréhension de leurs besoins autécologiques avant qu'aucun effort de conservation durable puisse être appliqué avec succès. Par conséquent, l'article vise à analyser la présence de ces

(1) West University of Timisoara, Faculty of Chemistry, Biology, Geography, Dept. of Biology, 16A Pestalozzi St., 300115 Timisoara, Romania, parvulescubio@cbg.uvt.ro

(2) Roehampton University, School of Life Sciences, Center for Research in Ecology, Holyborne Avenue, SW15 4JD, London, UK, O.Pacioglu@roehampton.ac.uk

(3) National Administration "Romanian Waters", Department of Water Resources Management, 6 Edgar Quinet St., Bucharest, Romania, carmen.hamchevici@rowater.ro 
Austropotamobius deux espèces d'écrevisses dans les montagnes d'Anina (Roumanie) par rapport à torrentium, écrevisses, distribution plusieurs indicateurs physico-chimiques mesurés sur les sites. Les résultats suggèrent que les impacts anthropiques enregistrés dans certains des sites d'échantillonnage ont pu influencer la disparition de ces deux espèces. Elles présentent des exigences écologiques similaires, ce qui suggère que l'espèce $A$. astacus est plus résistante à la pollution organique que $A$. torrentium. Néanmoins, l'absence de cohabitation des populations de ces deux espèces est également discutée.

\section{INTRODUCTION}

Various species of macroinvertebrates are used as bioindicators in the assessments of water quality, providing in this way useful tools for the management or the preservation of freshwater habitats (Rosemberg and Resh, 1993; Wright et al., 2000; Badea et al., 2010). In the calculation of the BMWP index, a value of 8 (out of a possible 10) has been attributed to Astacidae. Therefore, the presence of this family is usually indicating a "good" up to a "very good" water quality (Chapman et al., 1996). A few studies up to date have been conducted on crayfish, most of them on the conspecific Austropotamobius pallipes (Lereboullet, 1858), and proved that its presence was closely related to a good water quality (Broquet et al., 2002); however, they were unable to explain the absence/presence of this species based solely on the water physical-chemical characteristics (Demers and Reynolds, 2002). Another study revealed that most of the time, two species of crayfish do not cohabit in the same river stretch and that the actual factors that could delimit their distribution can be assessed throughout the type of substratum rather than the water quality (Lachat and Laurent, 1987).

The factors that delimit the geographical distribution of crayfish species can be explained by the synergic combination of several ecologic parameters (Payne, 1986). The crayfish taxa are vulnerable to various threats like their overexploitation, habitat modifications, water pollution, increasing pressure from other invasive crayfish species, or the crayfish plague (Lowery and Hogger, 1986; Gherardi and Holdich, 1999; Füreder et al., 2003; Lyons and Kelly-Quinn, 2003; Holdich and Pöckl, 2005). Austropotamobius torrentium (Schrank, 1803) has a IUCN "data deficient" status (Füreder et al., 2010) and is considered as a "priority species" by the Habitats Directive (European Communities, 1992). Astacus astacus (Linnaeus, 1758) has a "vulnerable" IUCN status (Edsman et al., 2010). Austropotamobius torrentium was declared as being a good indicator of water quality (Streissl and Hödl, 2002) due to its high intolerance for water pollutants (Machino and Füreder, 2005). Moreover, it has been proved that the anthropogenic impacts, e.g. changes of the river bed morphology, could have a considerable negative impact on these species that may even lead to the extinction of the affected populations (Lowery and Hogger, 1986).

There are three indigenous crayfish species living in Romania: the stone crayfish A. torrentium, the noble crayfish $A$. astacus and the narrow-clawed crayfish Astacus leptodactylus Eschscholtz, 1823 (Băcescu, 1967; Holdich, 2002; Pârvulescu, 2010). The issues related to the distribution of these crayfish species in relationship to water quality have never been approached in Romania so far. Therefore, in accordance to the requirements of the Water Framework Directive and conservative issues underlined by IUCN (see above), this study will try to infer qualitative and quantitative information about the autecology of these two species of crayfish, their correlation with the water quality and their interspecific relations. The heterogeneity of the habitats found in the Anina Mountains offers the natural background for testing such hypotheses, although characteristic for a local area, since this survey accounted for only one type of geology: the limestone rivers (Bleahu and Rusu, 1965). 


\section{MATERIALS AND METHODS}

The Anina Mountains, where this survey was conducted, are localized in the south-west of Romania (Figure 1) and are drained by the three distinct catchments of the rivers Bârzava, Caraş and Nera. Two crayfish species live in this area: the noble crayfish (A. astacus) and the stone crayfish (A. torrentium) (Pârvulescu, 2009). The investigated zone is a mountain dominated area situated in the SW of Carpathians Mountains, with a predominant calcareous geology and a maximum altitude of $1160 \mathrm{~m}$ a.s.I. (Bleahu and Rusu, 1965). The sampled area comprised two national parks: the Semenic - Cheile Caraşului National Park and the Cheile Nerei - Beuşniţa National Park. The investigated rivers are draining this limestone deposit: the rivers of Caraş and Nera are tributaries of the Danube River, whilst the waters of the Bârzava River reach the Danube only after the confluence with the River Timiş, being therefore a secondary tributary (Figure 1). This latter region is considered as being moderately impacted by industrialization (Ujvari, 1972).

The sampling campaigns were carried out during two consecutive years (2008 and 2009) in 52 stations, located towards the headwaters of the Bârzava, Caraş and Nera catchments in Anina Mountains. The sampling period took place during the summer months, since during this time of the year the hydrologic unit is characterized by a constant base flow (Ujvari, 1972), discarding therefore the undesirable biases of floods. The individuals were collected directly by hand from the riverbed, through checking the galleries within banks and the spaces between rocks and the roots of macrophytes over a distance of $300 \mathrm{~m}$ river stretch/each sampling site. Where individuals have not been found by this method, the active search continued over a distance of 500 m river stretch, additionally by installing 10 traps on the river bed separated by a $10 \mathrm{~m}$ distance, using fresh liver as bait. If finally, all these efforts proved to be useless with respect to the capture success, the site was declared as being "absent" (containing no crayfish).

The physical-chemical parameters were measured in triplicate in each of the 52 sampling stations and they comprised: temperature, $\mathrm{pH}$, dissolved oxygen, chemical oxygen demand (by CCO-Cr method, based on the oxidation of organic substances from the water with sulphuric acid mixed with potassium dichromate), water hardness (given by sum of the dissolved calcium and magnesium ions), sum of tannins and lignin (refractory organic matter - ROM), detergents, cyanides, dissolved inorganic nitrogen species (as $\mathrm{N}$-ammonium, $\mathrm{N}$-nitrites and $\mathrm{N}$-nitrates, expressed as $\mathrm{mg} \mathrm{N}-\mathrm{X} \cdot \mathrm{L}^{-1}$ ) and soluble reactive phosphorus (SRP, measured as $\left.\mathrm{mg} \mathrm{P}-\mathrm{PO}_{4} \cdot \mathrm{L}^{-1}\right)$. These indicators were recorded by in-situ measurements with HACH-Lange multiparameter and spectrophotometer field equipments following the standard procedure for each element. Morphological parameters of the river, like the width, depth and the degree of cover by the canopy (expressed in percentages) were registered as well. The mean abundance of crayfish, disregarding the appurtenance to any sex or size class, was estimated by the CPUE method (Demers and Reynolds, 2006) and expressed as mean number of individuals. $100 \mathrm{~m}^{-1}$ river stretch.

The abundance of the crayfish species were firstly normalized by $\log (x+1)$ and simply logged for the physical-chemical parameters. After meeting the criteria for normality (KolmogorovSmirnof test, $p>0.05$ ), an independent $t$ test was employed in order to compare the differences in the physical-chemical parameters among the sites were both species were considered as being present or absent. A principal component analysis (PCA) was undertaken for the habitat parameters for both species, for a better illustration of their variation over the sampling sites. The eigenvalues and the percentage explained by the first both axis were estimated. In order to reveal the relationships between the abundance of every species of crayfish and the abiotic factors, Pearson correlation coefficients were used. By utilizing the step wise linear regression method, a regression equation was calculated for both species, in order to explain the potential synergic effect of different physical-chemical factors over their abundance. The data were analyzed in SPSS 17 and CANOCO 4.5 for Windows. 


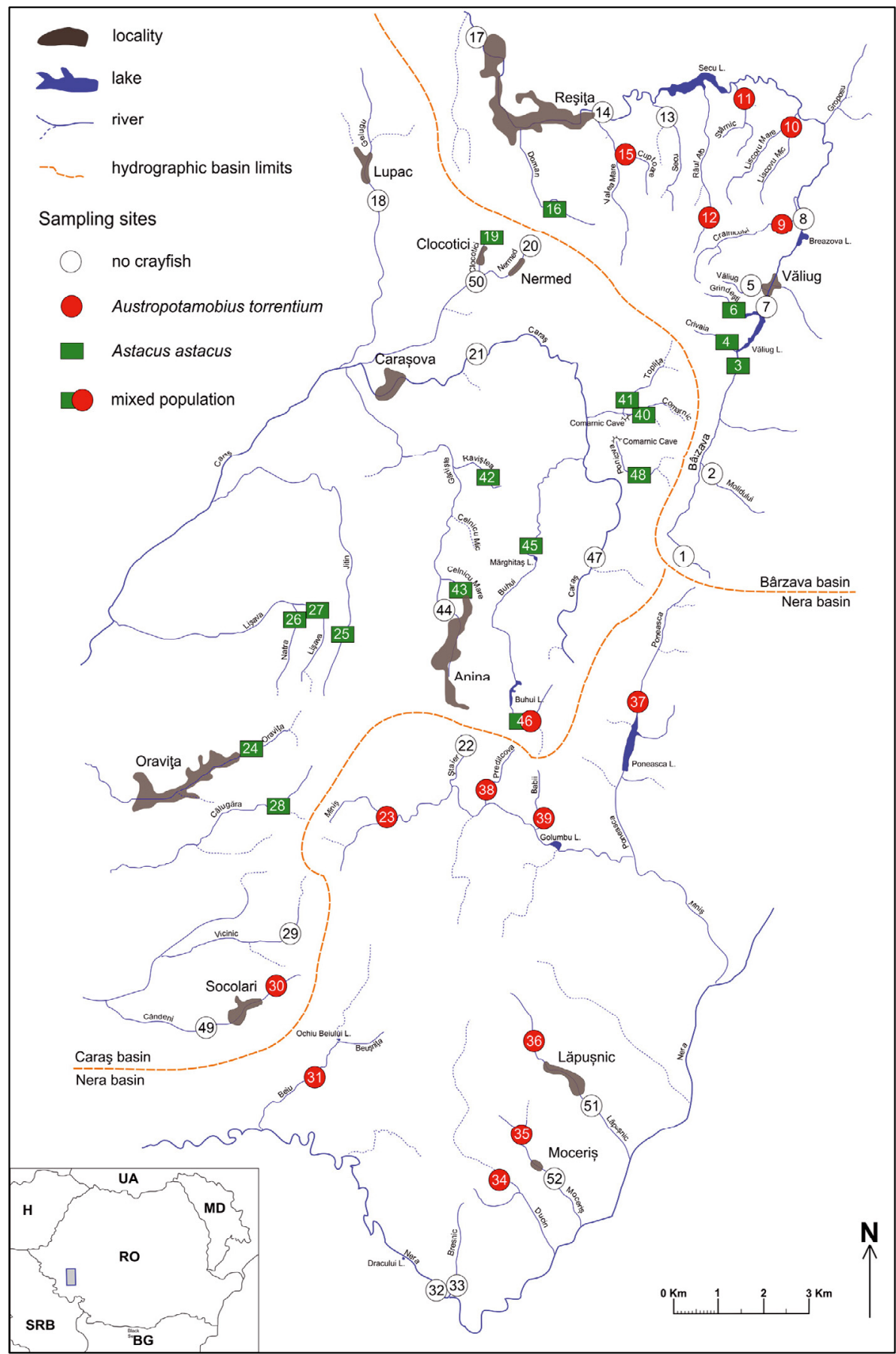

Figure 1

The geographic distribution of the two crayfish species in the Anina Mountains with the mention of sampling sites.

Figure 1

Distribution géographique des deux espèces d'écrevisses dans les montagnes d'Anina avec localisation des sites d'écahantillonnage. 


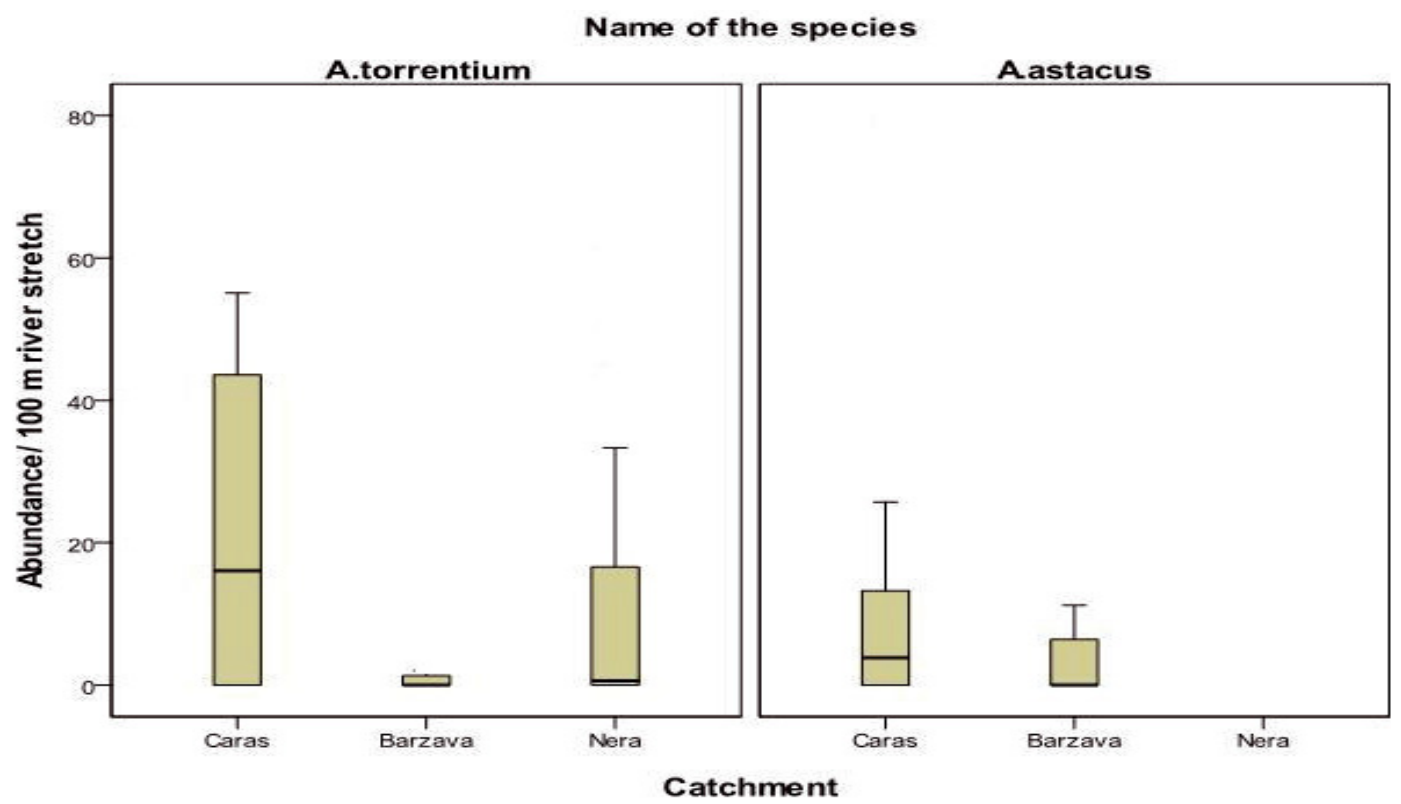

Figure 2

Distribution (as box plots) of each crayfish species abundance/catchments.

Figure 2

Distribution de la densité de chacune des espèces d'écrevisses/bassin versant.

\section{Table I}

Mean density $100 \mathrm{~m}^{-1}$ river stretch and S.E. for each crayfish species/catchment ( $N=$ number of captured individuals from each species/each catchment).

\section{Tableau I}

Moyennes des densités par $100 \mathrm{~m}$ de tronçon de rivière et erreur-standard pour chaque espèce d'écrevisse et bassin versant ( $N$ = nombre d'individus capturés de chaque espèce et bassin versant).

\begin{tabular}{|l|c|c|c|c|}
\hline Catchment & Name of the species & Mean & $N$ & Std. error of mean \\
\hline \multirow{2}{*}{ Caraş } & A. torrentium & 21.8 & 4 & 13.4 \\
\cline { 2 - 5 } & A. astacus & 12.75 & 40 & 3.3 \\
\hline \multirow{2}{*}{ Bârzava } & A. torrentium & 2.94 & 28 & 1.4 \\
\cline { 2 - 5 } & A. astacus & 2.91 & 18 & 0.99 \\
\hline Nera & A. torrentium & 10.5 & 26 & 3.46 \\
\hline
\end{tabular}

\section{RESULTS}

In the three investigated catchments from the Anina Mountains, the species $A$. torrentium was found mainly in the rivers of Nera and Bârzava, although it has been discovered scattered in two other locations on the Caraş catchment (Figure 1). The species $A$. astacus was present as well in the Caraş watershed, along with its discovery in a few lakes from the Bârzava catchment (similar density with the other species), but never found in the Nera catchment (see Figure 2 and Table I).

A two way ANOVA test applied for $\log (x+1)$ abundances revealed no significant differences for each species density amid catchments, years of sampling or the interaction between them (for $A$. torrentium; rivers $-F=2.5, p=0.09$; years $-F=0.01, p=0.92$, rivers ${ }^{*}$ years interaction $F=0.6, p=0.55$, and for $A$. astacus; rivers $-F=3.14, p=0.08$, years $-F=0.14, p=0.7$, rivers*years interaction $-F=0.22, p=0.64$ ).

Tables II and III present the values of the means and standard error of the means of the physical-chemical parameters measured for every species of crayfish, split on the locations registered as "present" or "absent". 
Table II

Mean and S.E. values for the physical-chemical parameters measured for Austropotamobius torrentium ( $p$ values bolded for $p$ values with ${ }^{*}<0.05$, and ${ }^{* *}$ for $<0.01$ ). The independent $t$ test was run on logarithmical values.

\section{Tableau II}

Moyennes et écart-types des paramètres physico-chimiques mesurés pour Austropotamobius torrentium (les valeurs de $p$ sont en gras avec * pour $p<0,05$, et ${ }^{* *}$ pour $p<0,01$ ). Le test $t$ d'indépendance est réalisé sur les valeurs logarithmiques.

\begin{tabular}{|c|c|c|c|}
\hline Parameter & $\begin{array}{c}\text { Sites where } \\
\text { crayfish present }\end{array}$ & $\begin{array}{c}\text { Sites were } \\
\text { crayfish absent }\end{array}$ & $\begin{array}{c}p \text { value of the } \\
\text { independent } t \text { test }\end{array}$ \\
\hline Altitude & $396 \pm 119.3$ & $400.7 \pm 28.6$ & 0.421 \\
\hline $\mathrm{pH}$ & $8.04 \pm 0.3$ & $7.8 \pm 0.4$ & $0.02^{*}$ \\
\hline Conductivity & $263.72 \pm 134.47$ & $280 \pm 193.77$ & 0.42 \\
\hline Temperature & $18.74 \pm 3.6$ & $18.53 \pm 4.4$ & 0.65 \\
\hline Water hardness & $6.91 \pm 3.11$ & $6.11 \pm 3.74$ & 0.139 \\
\hline Calcium & $47.14 \pm 20.2$ & $38.06 \pm 23.56$ & 0.054 \\
\hline Magnesium & $9.4 \pm 1.64$ & $6.84 \pm 3.74$ & 0.933 \\
\hline Detergents & $0.05 \pm 0.046$ & $0.48 \pm 0.06$ & $<0.01^{\star *}$ \\
\hline ROM & $0.68 \pm 0.57$ & $0.48 \pm 0.06$ & 0.521 \\
\hline Oxygen deficit & $3.44 \pm 0.62$ & $4.6 \pm 2.43$ & $0.023^{\star}$ \\
\hline N-nitrates & $1.05 \pm 0.6$ & $3.06 \pm 2.54$ & $<0.01^{\star \star}$ \\
\hline N-nitrites & $0.01 \pm 0.021$ & $0.04 \pm 0.04$ & $<0.01^{* *}$ \\
\hline SRP & $0.18 \pm 0.12$ & $0.35 \pm 0.32$ & $0.014^{*}$ \\
\hline N-ammonium & $0.06 \pm 0.08$ & $0.25 \pm 0.7$ & 0.134 \\
\hline Dissolved oxygen & $8,93 \pm 0.7$ & $7.91 \pm 1.2$ & $<0.01^{* *}$ \\
\hline Width of the river & $1.51 \pm 0.8$ & $2.84 \pm 2.11$ & $0.002^{*}$ \\
\hline Water depth & $0.24 \pm 0.37$ & $0.34 \pm 0.32$ & $0.025^{\star}$ \\
\hline Coverage \% & $68.06 \pm 31.4$ & $62.15 \pm 23.7$ & 0.121 \\
\hline Cyanides & $0.0048 \pm 0.002$ & $0.0057 \pm 0.002$ & 0.495 \\
\hline
\end{tabular}

The first and the second axis of the PCA ordination of physical-chemical parameters for A. torrentium over the presence/absence sites (Figure 3) explained $50.42 \%$ of their variance (the first axis explaining $28.42 \%$ ). The eigenvalues of the first axis were 5.4 and respectively 4.1, eligible for being taken into consideration based on the "broken stick" model (Shaw, 2003). The sites where this species of crayfish has been found are more clustered towards the origin, with a certain degree of overlapping with the sites where the crayfish was absent, although a scatter between the two type of sites are plotted along the main axis. The main gradients are represented along the first axis and can be interpreted in the way that the sites where the species have been found are situated at higher altitudes, with narrower tributaries, less shadowed and highly oxygenated. At the other extreme lie the physical-chemical parameters that are reversely related to the altitude, like the water conductivity, calcium, magnesium, $\mathrm{N}$-species, phosphorous, detergents, oxygen deficit, all good indicators of organic pollution. An increase in width and depth of the rivers is noticed as well along the same axis.

The first and the second axis of the PCA ordination of physical-chemical parameters over present/absent sites for $A$. astacus (Figure 4) was very similar in pattern with the one noticed for $A$. torrentium, although with a smaller degree of sites clustering. Nevertheless, the first and the second axis explained $49.97 \%$ from the variation (the first axis explaining $22.27 \%$ ), with eigenvalues of 4.23 , respectively of 3.93 , again eligible for being considered in the analysis, in accordance to the same "broken stick" model.

The Pearson coefficients revealed moderately significant positive correlations among the $\log (x+1)$ abundance of $A$. torrentium with parameters like: the conductivity $(r=0.263$, $p<0.05)$, water hardness and calcium $(r=0.312, p<0.05$ and $r=0.37, p<0.01)$, the dissolved oxygen $(r=0.335, p<0.05)$, and significantly negative with chemical species 


\section{Table III}

Means and S.E. values for the physical-chemical parameters measured for Astacus astacus ( $p$ values bolded for $p$ values with ${ }^{*}<0.05$, and ${ }^{* *}$ for $\left.<0.01\right)$. The independent $t$ test was run on logarithmical values.

\section{Tableau III}

Moyennes et écart-types des paramètres physico-chimiques mesurés pour Astacus astacus (les valeurs de $p$ sont en gras avec * pour $p<0,05$, et ${ }^{* *}$ pour $\left.p<0,01\right)$. Le test $t$ d'indépendance est réalisé sur les valeurs logarithmiques

\begin{tabular}{|l|c|c|c|}
\hline Parameter & $\begin{array}{c}\text { Sites where } \\
\text { crayfish present }\end{array}$ & $\begin{array}{c}\text { Sites were } \\
\text { crayfish absent }\end{array}$ & $\begin{array}{c}\text { p value of the } \\
\text { independent } t \text { test }\end{array}$ \\
\hline Altitude & $460.3 \pm 24.4$ & $357.25 \pm 29.03$ & $\mathbf{0 . 0 0 3}^{\star}$ \\
\hline pH & $7.9 \pm 0.04$ & $7.8 \pm 0.07$ & 0.225 \\
\hline Conductivity & $325.5 \pm 38.67$ & $362.2 \pm 46.6$ & 0.799 \\
\hline Temperature & $16.5 \pm 0.4$ & $17.01 \pm 0.75$ & 0.758 \\
\hline Water hardness & $9.88 \pm 1.26$ & $8.95 \pm 1.17$ & 0.85 \\
\hline Calcium & $64.92 \pm 8.7$ & $53.4 \pm 7.4$ & 0.515 \\
\hline Magnesium & $7.27 \pm 1.23$ & $7.63 \pm 1.64$ & 0.611 \\
\hline Detergents & $0.05 \pm 0.01$ & $0.24 \pm 0.08$ & $\mathbf{0 . 0 0 8}{ }^{\star}$ \\
\hline ROM & $0.67 \pm 0.7$ & $0.5 \pm 0.12$ & 0.017 \\
\hline Oxygen deficit & $3.35 \pm 0.12$ & $5.22 \pm 0.73$ & $\mathbf{0 . 0 0 6}$ \\
\hline N-nitrates & $1.52 \pm 0.16$ & $2.83 \pm 0.35$ & $\mathbf{0 . 0 0 5}$ \\
\hline N-nitrites & $0.01 \pm 0.003$ & $0.03 \pm 0.01$ & 0.107 \\
\hline SRP & $0.22 \pm 0.05$ & $0.27 \pm 0.61$ & 0.529 \\
\hline N-ammonium & $0.05 \pm 0.013$ & $0.28 \pm 0.15$ & 0.061 \\
\hline Dissolved oxygen & $8.67 \pm 0.14$ & $7.65 \pm 0.37$ & 0.125 \\
\hline Width of the river & $1.95 \pm 0.22$ & $2.72 \pm 0.4$ & 0.126 \\
\hline Waters depth & $0.24 \pm 0.03$ & $0.4 \pm 0.04$ & $\mathbf{0 . 0 4 8}{ }^{\star}$ \\
\hline Coverage \% & $66.9 \pm 5.11$ & $59.08 \pm 5.05$ & 0.568 \\
\hline Cyanides & $0.005 \pm 0.001$ & $0.0044 \pm 0.001$ & 0.493 \\
\hline
\end{tabular}

like the deficit of oxygen $(r=-314, p<0.01)$, N-nitrates $(r=-0.526, p<0.01)$, N-nitrites $(r=-0.438, p<0.01)$, and the river width $(r=-0.31, p<0.05)$. The same type of analysis outlined similar patterns for the species $A$. astacus, that correlated positively with the dissolved oxygen ( $r=0.261, p<0.05), \mathrm{pH}(r=0.3, p<0.05)$, ROM $(r=0.38, p<0.05)$, calcium $(r=0.275, p<0.05)$ and negatively with the detergents $(r=-0.27, p<0.05)$, oxygen deficit $(r=-0.33, p<0.05)$ and $\mathrm{N}$-nitrates $(r=-0.36, p<0.01)$. The linear regression equations relating the abundance of both species, by using the step wise model was expressed by the following mathematical equations:

Log abundance $A$. torrentium $=0.1+1.65 \times \log \mathrm{Ca}-2.85 \times \log$ oxygen deficit $\left(R^{2}=0.23\right.$, $p<0.05)$

Log abundance $A$. astacus $=1.06+0.95 \times \log \mathrm{Ca}-2.33 \times \log$ oxygen deficit $\left(R^{2}=0.16\right.$, $p<0.05)$.

\section{DISCUSSION}

The dynamic of both species of crayfish did not fluctuate significantly during the study period (2008-2009), with the highest mean density for both species being registered in the Caraş catchment. The two way ANOVA test revealed no significant differences in the species density between years and catchments for both species, revealing stable populations, at least for the sampled period. The stone crayfish was almost twice more abundant than the noble crayfish in the Caraş catchment and the latter was completely absent in the River Nera (Table I). 


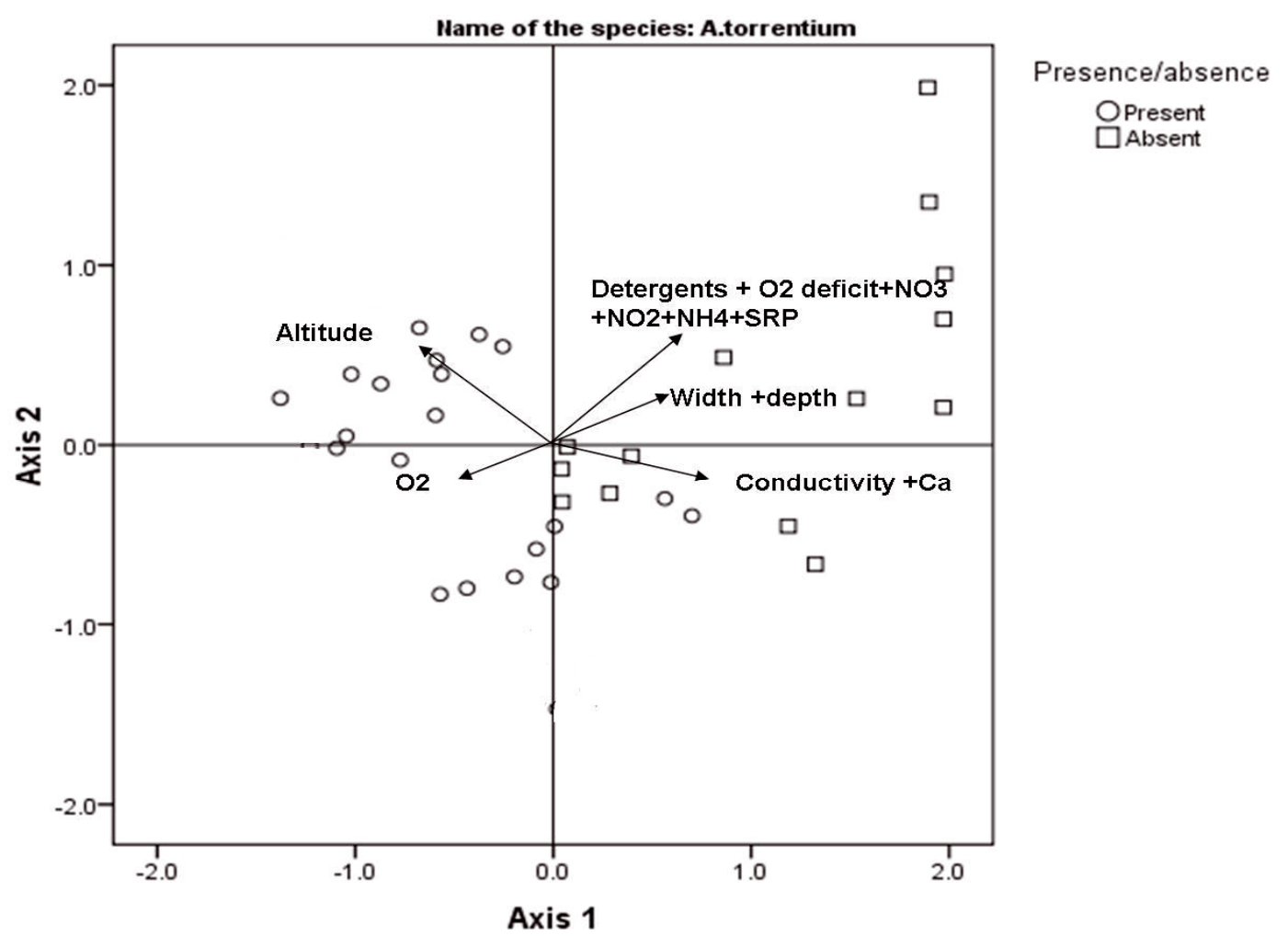

Figure 3

PCA ordination of the physical-chemical parameters over the presence/absence sites for the species Austropotamobius torrentium.

Figure 3

Analyse en coordonnées principales des paramètres physico-chimiques sur la présence/absence des sites de l'espèce Austropotamobius torrentium.

The sites where both species of crayfish were present/absent revealed certain environmental parameters as being significantly different (Tables II and III). The general trend, as illustrated by the PCA ordination, is a decrease of the concentrations of the dissolved oxygen, $\mathrm{ROM}, \mathrm{pH}$, water hardness, calcium and magnesium, and an increase of nitrogen species, SRP, oxygen deficit, cyanides, detergents, width and depth or the rivers along an upstreamdownstream transect. Most of the sites where the crayfish were absent were situated downstream villages (e.g. Lupac, Clocotici, Socolari, Lăpuşnic or Moceriş) or towns (e.g. Anina and Reşiţa) or downstream sewage treatment plants, eutrophic pond outflows or deforestation sites (Figure 1).

The results strongly suggest that both species are sensitive to water organic pollution, as revealed by the significant negative correlations of the stone crayfish to the deficit of dissolved oxygen, nitrates, nitrites or the increased width of the river. Previous studies have found this species as being restricted to small alpine brooks in Germany (Renz and Breithaupt, 2000), although reaching "unusual" habitats, like in lake Constance, with a saprobial index of 2, indicating therefore a moderately polluted habitat. The positive correlations with calcium and water hardness are anyway typical not only for Malacostraca, but noticed in general for all the crustaceans and the mollusks (Leiden and Botoşăneanu, 1998). The average concentrations found for this species in this study are consistent with other concentrations, between 50-100 mg Ca. $\mathrm{L}^{-1}$, as has been reported for this species in the south of Germany by Reinz and Breithaupt (2000) or by Bohl (1989) in Bavaria. The negative correlation with nitrites, due their increase in the rivers as a result of point/diffuse pollution was investigated in laboratory experiments on the noble crayfish (Jensen, 1996) for concentrations of $1 \mathrm{mM} \cdot \mathrm{L}^{-1}$, much 


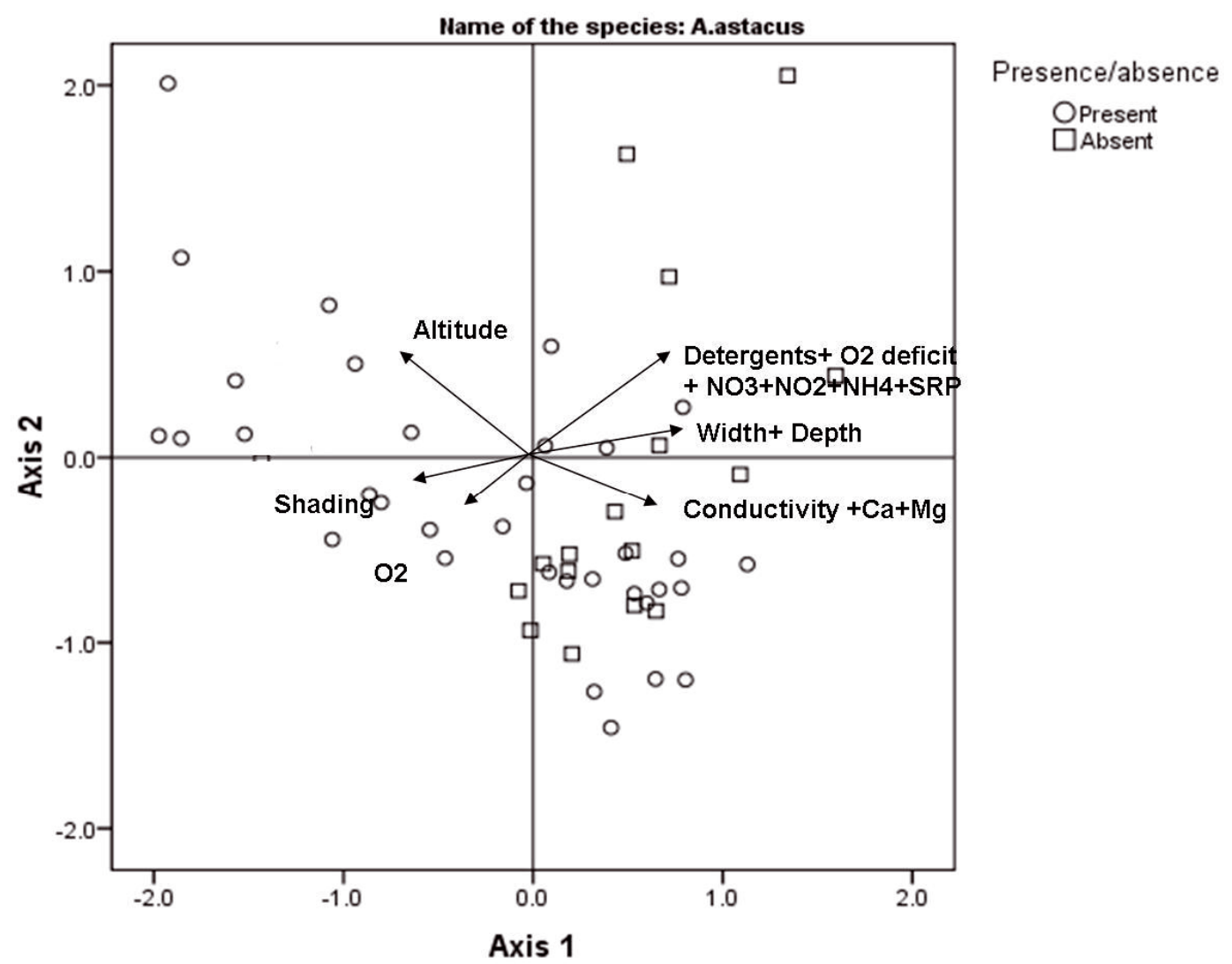

Figure 4

PCA ordination of the physical-chemical parameters over the presence/absence sites for the species Astacus astacus.

Figure 4

Analyse en coordonnées principales des paramètres physico-chimiques sur la présence/absence des sites de l'espèce Astacus astacus.

higher then the values registered for this survey (means 0.03 or $0.04 \mathrm{mg} \mathrm{N}-\mathrm{NO}_{2} \cdot \mathrm{L}^{-1}$ for both species). The nitrates were revealed by Jensen (1996) as being a relatively non toxic element and were rather indicated as a byproduct of the nitrites oxidation in the haemolymph, when the organism is exposed to high concentrations of the latter chemical species. The significant correlation with the dissolved oxygen and implicitly the negative correlations with its deficit, are underlining once again the preference of both species for a pristine environment, with a possible certain degree of toleration to organic pollution, but only up to a moderate scale (indicated as well by the degree of sites overlapping in the PCA ordination plot near the origin). Prolonged periods of hypoxia (although not registered in our study, but possible during summer time when the river is characterized by a minimum base flow), as revealed by Demers et al. (2006), induce an increase in the haemolymph concentration of calcium, as a possible buffer of the acid-base variations that do occur, with an additional possible threat, being the dissolution of calcium carbonate from the exoskeleton (Truchot, 1979; Wheatly and Henry, 1992). Therefore, the short term adaptation to lower oxygen conditions (as those registered downstream the urban/rural sites) produces an increase of blood $\mathrm{pH}$ and calcium concentrations, resulting in an increase of the haemocyanin affinity for oxygen (Mangum, 1980). These types of relations were revealed as well in the linear regression equation established for both species of crayfish during this survey, where the positive effect of calcium concentrations and the negative effect of oxygen deficit explained $23 \%$, and respectively $16 \%$ of species mean densities. The significant negative correlation of stone crayfish with the river width is 
in accordance with other studies (Machino and Füreder, 2005; Vlach et al., 2009), that revealed the preference of this species for small to medium sized river stretches. This was obviously underlined as well by the geographic distribution of this species in the studied area, being found in sites situated at higher altitude than for the noble crayfish (Figure 1). The increase in rivers width represents a direct impact of urbanization, noticed mainly in the river stretches situated downstream the aforementioned villages and towns, where both species were generally absent.

The noble crayfish had therefore similar autecologic requirements to the stone crayfish. Nevertheless the smaller $R^{2}$ value for the regression equations and less significant correlations with the environmental parameters, do suggest that it could be a species more tolerant to organic pollution than the stone crayfish. The positive correlation with calcium could be as well related to its maintenance of an optimum level of water permeability (Rasmusen and Bjerregars, 1995), a mechanism potentially involved for other freshwater crustaceans. The negative correlation with the detergents, suggest that a mean concentration of the detergents of $0.24 \mathrm{mg} \cdot \mathrm{L}^{-1}$ might be harmful for this species.

Another interesting finding of this survey was that only in one investigated locality from a total of 52, during two years survey, both species occurred together. Therefore, these data, and those from a much wider survey of the Romanian territory (Pârvulescu L., unpublished data) do suggest that these two species do not coexist in the same river stretch. A possible explanation for this situation might underlie from the fact that both species might have similar autecologic requirements, therefore rejecting one another. The trophic spectrum of the stone crayfish is very wide, including flatworms, leeches, freshwater crayfish, mussels, and even sticklebacks, besides the usual detritus diet (Reinz and Breithaupt, 2000). The same type of diet might be preferred as well by the noble crayfish (Băcescu, 1967). Therefore, it would be plausible to consider that due similar ecologic requirements, the populations of both species might be actually avoiding one another.

An alternative explanation would be the hypothesis of a more "phylogenetic" scenario, involving the dispersal history. Trontelj et al. (2005) strongly suggested that the epicenter of dispersal for the stone crayfish was on the territory of former Yugoslavia, from where it dispersed slowly, but actively, during the Pleistocene towards the Central and Eastern Europe territories, including Romania. The genetic analysis of western and central European populations revealed the fact that as compared to other species from the same genus, $A$. torrentium is rather a homogenous species, sharing the characteristics of a monophyletic origin, implicating a much more recent dispersal history then expected for other groups of freshwater organisms from the former Tethys basin (Bï乏jnïßjrescu, 1992). The dispersal of the noble crayfish could have happened in different times, the actual distribution of these two species reflecting therefore slowly colonizing populations moving towards the headwaters of different catchments. It is known that this species has a negative interaction with the stone crayfish, and that on their turn both of them do have negative interactions with $A$. leptodacylus, due the more aggressive and efficient ecologic and reproductive strategies of this latter species (Stucki and Romer, 2001). Nevertheless, this type of hypothesis have not yet been tested on the Romanian populations, but those undertaken on the Balkans by Trontelj et al. (2005) do support this kind of scenario. To further track the colonization history or to test for alternative hypothesis of ecologic exclusions, more samples from wider areas are needed, like those suggested for the western Romania and genetic studies, in order to compare different populations from eastern Danube hydrographical basin.

\section{ACKNOWLEDGEMENTS}

We are very grateful to the two anonymous reviewers, for their constructive criticize, very helpful comments and suggestions. We want to thank equally to Ms Adriana Vizitiu, "Romanian Waters" Company, Banat county for the technical support of water chemical analysis. We would like to thank all the students that participated actively in the fieldwork. This study was funded by CNCSIS-UEFISCDI Exploratory research projects PCE-4, grant no 1019/2008 
"The stone crayfish (Austropotamobius torrentium), distribution in Romanian habitats, ecology and genetics of populations".

\section{REFERENCES}

Băcescu M.C., 1967. Fauna Republicii Socialiste România - Crustacea, Decapoda, Editura Academiei Republicii Socialiste România, București.

Badea A.B., Gagyi-Palffy A., Stoian L.C. and Stan G. 2010. Preliminary studies of quality assessment of aquatic environments from Cluj suburban areas, based on some invertebrates bioindicators and chemical indicators. Aquaculture, Aquarium, Conservation \& Legislation - International Journal of the Bioflux Society, 3, 35-41.

Bănărescu P., 1992. Zoogeography of freshwaters. Distribution and dispersal of freshwater animals in North America and Eurasia, Aula-Verbag, Wiesdeban, Germany.

Bleahu M. and Rusu T., 1965. Romanian karst. A general overview. Lucrările Institutului de Speologie "Emil Racoviţă", 59-73.

Bohl E., 1989. An isolated population of the white-clawed crayfish (Austropotamobius pallipes) in the principality of Liechtenstein. Bull. Fr. Pêche Piscic., 347, 701-747.

Broquet T., Thibault M. and Neveu A., 2002. Distribution and habitat requirements of the white-clawed crayfish, Austropotamobius pallipes, in a stream from the Pays de Loire region, France: an experimental and descriptive study. Bull. Fr. Pêche Piscic., 367, 717-728.

Chapman D., Jackson J. and Krebs F., 1996. Water quality monitoring - A practical guide to the design and implementation of Freshwater Quality Studies and Monitoring Programmes, Chapter 11. In: Bartram J. and Balance R. (eds.), Biological monitoring, UNEP/WHO, 267-305.

Demers A. and Reynolds J.D., 2002. A survey of the white-clawed crayfish, Austropotamobius pallipes, (Lereboullet), and of water quality in two catchments of eastern Ireland. Bull. Fr. Pêche Piscic., 367, 729-740.

Demers A. and Reynolds J.D., 2006. Water quality requirements of the white-clawed crayfish, Austropotamobius pallipes, a field study. Freshwater Crayfish, 15, 283-291.

Demers A., Souty-Grosset C., Trouilhe M.C., Füreder L., Renai B. and Gherardi F., 2006. Tolerance of three European native species of crayfish to hypoxia. Hydrobiologia, 560, 425-432.

Edsman L., Füreder L., Gherardi F. and Souty-Grosset C., 2010. Astacus astacus. In: IUCN 2010, IUCN Red List of Threatened Species, Version 2010.4, www.iucnredlist.org. Downloaded on 26 November 2010.

European Communities, 1992. Council Directive (92/43/EEC) on the conservation of natural habitats and of wild fauna and flora, The Council of European Communities.

Füreder L., Oberkofler B., Hanel R., Leiter J. and Thaler B., 2003. The freshwater crayfish Austropotamobius pallipes in South Tyrol: heritage species and bioindicator. Bull. Fr. Pêche Piscic., 370-371, 79-95.

Füreder L., Gherardi F. and Souty-Grosset C., 2010. Austropotamobius torrentium. In: IUCN 2010, IUCN Red List of Threatened Species. Version 2010.4, www.iucnredlist.org. Downloaded on 26 November 2010.

Gherardi F. and Holdich D.M., 1999. Crayfish in Europe as alien species. How to make the best of a bad situation, Crustacean Issues, 11, A.A. Balkema, Rotterdam, Brookfield.

Holdich D.M., 2002. Distribution of crayfish in Europe and some adjoining countries. Bull. Fr. Pêche Piscic., 367, 611-650.

Holdich D.M. and Pöckl M., 2005. Does legislation work in protecting vulnerable species? Proceeding of CRAYNET Innsbruck conference 2004. Bull. Fr. Pêche Piscic., 376-377, 809-827.

Jensen F.B., 1996. Uptake, elimination and effects of nitrite and nitrate in freshwater crayfish (Astacus astacus). Aquat. Toxicol., 34, 95-104.

Lachat G. and Laurent P.J., 1987. The habitats of Astacus astacus L. and Austropotamobius pallipes Lere. in the Morvan. Freshwater Crayfish, 7, 61-68.

Leiden L. and Botoşăneanu L., 1998. Studies in crenobiology. The biology of springs and springbrooks, Backhuys Publishers, Leiden. 
Lowery R. and Hogger J., 1986. The effect of river engineering and disease on a population of Austropotamobius pallipes in the River Lea, UK. Freshwater Crayfish, 6, 94-97.

Lyons R. and Kelly-Quinn M., 2003. An investigation into the disappearance of Austropotamobius pallipes (Lereboullet) populations in the headwaters of the Nore River, Ireland and the correlation to water quality. Bull. Fr. Pêche Piscic., 370-371, 139-150.

Machino Y. and Füreder L., 2005. How to find a stone crayfish Austropotamobius torrentium (Schrank, 1803): a biogeography study in Europe. Bull. Fr. Pêche Piscic., 376-377, 507-517.

Mangum C.P., 1980. Respiratory function of the hemocyanins. Am. Zool., 20, 19-38.

Pârvulescu L., 2009. The epigean freshwater malacostracans (Crustacea: Malacostraca) of the rivers in the Anina Mountains (SW Romania). Studia Universitatis Babeç - Bolyai, seria Biologia, 54, 3-17.

Pârvulescu L., 2010. Crayfish field guide of Romania, Bioflux, Cluj-Napoca.

Payne J.F., 1986. Factors influencing patterns of crayfish distribution. Freshwater Crayfish, 6, 100-110.

Rasmusen A.D. and Bjerregars P., 1995. The effect of salinity and calcium concentration on the apparent water permability of Cherax destructor, Astacus astacus and Carcinus maenas (Decapoda, Crustacea). Comp. Biochem. Physiol., 1, 171-175.

Reinz M. and Braithaupt T., 2000. Habitat use of the crayfish Autropotamobius torrentium in small brooks and in Lake Constance, southern Germany. Bull. Fr. Pêche Piscic., 356, 139-154.

Rosenberg D.M. and Resh V.H., 1993. Freshwater biomonitoring and benthic macroinvertebrates, Chapman Hall, New York.

Shaw P.J.A., 2003. Multivariate Statistics for the Environmental Sciences, Oxford University Press Inc., New York.

Streissl F. and Hödl W., 2002. Habitat and shelter requirements of the stone crayfish Austropotamobius torrentium Schrank. Hydrobiologia, 477, 195-199.

Stucki T. and Romer J., 2001. Will Astacus leptodactylus replace Astacus astacus and Austropotamobius torrentium in lake Ageri, Switzerland? Aquat. Sci., 63, 477-489.

Trontelj P., Machino J. and Sket B., 2005. Phylogenetic and phylogeographic relationships in the crayfish genus Austropotamobius inferred from mitochondrial COI gene sequences. Mol. Phylogenet. Evol., 34, 212-226.

Truchot J.P., 1979. Mechanisms of the compensation of blood respiratory acid-base disturbances in shore crab, Carcinus maenas (Linee). Comp. Biochem. Physiol., 68A, 555-561.

Ujvari I., 1972. The geography of Romanian waters, Editura Ştiinţifică, Bucureçti (in Romanian).

Vlach P., Fischer D. and Hulec L., 2009. Microhabitat preference of the stone crayfish Austropotamobius torrentium (Schrank, 1803). Knowl. Manag. Aquatic Ecosyst, 384-395, 15.

Wheatly M.G. and Henry R.P., 1992. Extracellular and intracellular acid-base regulations in crustaceans. J. Exp. Zool., 2, 127-142.

Wright J.F., Sutcliffe D.V. and Furse M.F., 2000. Assessing the biological quality of fresh waters, RIVPACS and other techniques, Freshwater Biological Association, Ambleside, Cumbria. 